\title{
Sustainable Shifting Cultivation Using Agro-ecology Approach
}

\author{
Xuan Minh Tran \\ Institute of Land Management \\ Northeastern University \\ Shenyang, China 110819
}

\author{
Guoping Lei \\ Institute of Land Management \\ Northeastern University \\ Shenyang, China 110819
}

\author{
Ngoc Dan Nguyen \\ Institute of Land Management \\ Northeastern University \\ Shenyang, China 110819
}

\begin{abstract}
Traditional shifting cultivation is a long-standing practice that has contributed to self-sufficiency and self-supply in the lives of mountainous ethnic minorities in the long history. However, it is the direct cause of deforestation; Uncontrolled burning of vegetation is also a major cause of forest fires. At present, Vietnam has about 50 ethnic groups making shifting cultivation. Each ethnic group has its own characteristics in shifting cultivation, which reflects their perceptions, experiences, traditions and religious beliefs. The cycle of cultivation takes place at various stages and follows a very strict cultivation schedule: the main stages of the shifting cultivation cycle are: (i) site selection (in principle, generally select old forests, good soil, few bushes, vines, (iii) clear, (iv) prune(v) care, weed (vi) harvest (vii) abandon. Therefore, the best approach to improving and preserving soil quality is through the use of ecological agricultural practices: reuse of residues of crops and animal derived organic fertilizers, reduced use of chemicals in agriculture, promotion of cover crops, especially legumes, to protect and rehabilitate land. Care should be taken to develop techniques for maximizing biomass, ground cover and continuity of the cover to prevent soil erosion, enhance biological activity, enhance reproductive nutrition, create basic soil properties such as soil texture, organic content, porosity, $\mathrm{pH}$, etc. All these efforts are aimed at creating the best conditions for the growth and development of the crops. Studies show that management of shifting cultivation towards an agro-ecology approach is indispensable in the sustainable management and use of sloping land. This in fact has significantly increased yields on sloping crops, reduced erosion and income diversification for farmers while preserving resources and improving the environment, contributing to hunger elimination and poverty reduction and achievement of food security goals for the mountainous areas.
\end{abstract}

Keywords-shifting cultivation; agro-ecology; milpa; sustainable development

\section{INTRODUCTION}

Mountainous land occupies three-fourths of Vietnam's natural land. In general, these are difficult to use them inefficiently, especially when the soil has lost its cover. Most of the land area with a slope of less than $15^{\circ}(21.9 \%)$ has been used for agriculture or agroforestry. Land area with slope of $15 \mathrm{o}$ to $25 \mathrm{o}$ is about $16.4 \%$, the remaining land is sloping over $25^{\circ}(61.7 \%)$. Due to the lack of productive land, mountainous farmers still have to cultivate on land with the slope larger than $25^{\circ}$ under strong erosion [1]. Milpa is still a popular cultivation method contributing to self-sufficiency and self-supply of the life of mountainous ethnic minority people. Cultivation duration is shortened, usually only 2-3 crops of short-term crops, then planting cassava and fallow. Increasing population leads to a decrease in the average land area per capita, the fallow land is reduced to about 3 to 5 years. With such a short period, the soil fertility and physical and chemical properties of the soil have not been reproduced sufficiently for the growth and development of agricultural crops. Hence, crop productivity is very low and cultivation duration lasts only two crops. Low sloping land, due to the pressure of free grazing, irreversible vegetation, grass species for cattle cannot grow, except for grass, bitter grasses, has become bare land, bare hills with degraded so severe that it is difficult to recover if not high investment and timely. Weeds that are not of economic value thrive and compete fiercely with crops. As a result of the loss of forests, degraded land, low crop yields and reduced income from livestock, the lives of farmers in sloping land are very difficult and vicious in the cycle of poverty [2]

In order to have a more complete view of management, use and support for farmers master some of the agroecological techniques in sustainable shifting cultivation, we summarize the characteristics of shifting cultivation and introduce some sustainable cultivation techniques as well as perspectives on the use of agro-ecological approaches in sustainable forest research, management and utilization in mountainous areas of Vietnam. 


\section{GENERAL CHARACTERISTICS OF SHIFTING CULTIVATION IN VIETNAM}

At present, Vietnam has about 50 ethnic groups making shifting cultivation. Each ethnic group has its own characteristics in shifting cultivation, which reflects their perceptions, experiences, traditions and religious beliefs. However, we still see the common features of shifting cultivation in Vietnam [3]:

Cultivation system is a method of land use, in which a fragment of forest is cleared, usually by the fire, to plant some food plants in several crops, and then fallow to convert another fragment of forest;

The cycle of cultivation takes place at various stages and follows a very strict agriculture schedule: The main stages of the cultivation cycle are: (i) Site selection (in principle, (iii) burning, (iv) prune, (v) care, weed, (vi) harvest; (vii) abandon.

The shifting cultivation system is a complete cultivation system based on natural processes, without the addition of nutrients (fertilizers), therefore productivity depends entirely on nature and is very unstable.

In terms of nature, traditional shifting cultivation system has the following main characteristics: (i) All physical needs are met in a self-sufficient manner, from milpa economics and exploitation of natural resources in the forest ecosystem. Milpa is the main source of food as well as materials for weaving; The forest ecosystem provides building materials, firewood, and replenishment of food at intervals. The material and spiritual life of the people depends greatly on the forest ecosystem. Due to self-sufficiency, the largest production characteristics in their cultivation systems are multi-cropping. (ii) Culturally: the most outstanding feature is the very high community density that is evident in the modes of organization of labor such as public intercourse, labor exchange, mutual assistance. The second feature is the movement of the crop and the third feature is the agricultural ritual tied to the production stages of the cultivation cycle. Ritual activities in agriculture are customary due to the influence of the environment of living and national identity. In all of these customary activities, the role of village elders, village chiefs and dignitaries, the priests is very important. Analysis of the traditional cultivation systems of the people, we see:

Advantages: Cultivation system knows the flexible use of natural processes in household strategies. This is a cultivation system that does not require high levels of investment and simple cultivation techniques to suit the capacity of mountain farmers. This system does not use chemical fertilizers and pesticides, therefore, it is very clean.

Disadvantages: Cultivation system is only suitable for areas with high forest area, low population density (less than 50 people $/ \mathrm{km} 2$ ) and social pressure for forest is not great; totally dependent on the nature, therefore, the productivity is uncertain. On the other hand, because there is no factor of commodity production, shifting cultivation cannot be a way to improve the material life of mountainous people.
Today, the shifting cultivation of the people is greatly influenced by changes in the socio-cultural environment, the physical environment and the policy and institutional environment. The basic changes are [4]:

In the socio-cultural environment: social changes involve changes in community organization, population growth, especially migration of other ethnic groups into the region creates great pressure.

In the physical environment: the development of stateowned enterprises in the forest business and forest environment is limited both in quality and quantity due to various economic and social pressures.

In the policy and institutional environment: a series of policies of the State relating to socio-economic development and resource management in ethnic minority areas have created very basic advantages but also legal barriers restrict the choice of indigenous people from the perspective of their traditional cultivation systems. All of these factors have fundamentally altered the shifting cultivation practices: indigenous knowledge has been eroded, modern knowledge has not been sufficiently developed, cultivation systems become unstable, unsustainable and has been one of the main causes of deforestation.

Due to the said changes, the shifting cultivation system of mountainous people has changed considerably, with noticeable longer cultivation period and lower fallow period. In short, even some places have no time to fallow

The basic problem that mountain communities face every day is hunger and poverty. Their strategies for solving problems are mainly based on shifting cultivation and where they face many obstacles related to inputs, outputs and environmental factors. Key constraints can be summarized as follows [5]:

- The productivity of cultivation and husbandry is low due to: (i) Cultivation on sloping land, strong erosion and rapid soil fertility; (ii) Lack of proper agricultural cultivation techniques such as non-fertilized, unprotected, no-weeds, etc. because of lack of labor resources; (iii) Use of low yield local varieties.

- Share of commercial crops is low due to: (i) Lack of capital for production; (ii) Lack of market information and accessibility; (iii) lack of technologies and (iv) inadequate labor force.

- Income sources from forestry are insufficient or insignificant due to: (i) There is no appropriate allocation of land and forest to create economic opportunities for farmers; (ii) No incentive to raise awareness about forest protection and sustainable use.

These obstacles make the livelihood of the people unsustainable and therefore they are still shifting cultivation negatively affect natural forest resources. 


\section{BASIC DIRECTION IN SHIFTING CULTIVATION IN THE MOUNTAINOUS AREAS OF VIETNAM}

The best approach to improving and preserving soil quality is by applying agro-ecology measures: reuse of residues of crops and organic fertilizers of animal origin, reduction of chemical use in agriculture, enhancement in the application of cover crops, especially legumes, to protect and rehabilitate the soil. Care should be taken to develop techniques for maximizing biomass, ground cover and continuity of the cover to prevent soil erosion, enhance biological activity, enhanced reproductive nutrition processes, Create basic soil properties such as soil texture, organic content, porosity, $\mathrm{pH}$. All these efforts are aimed at creating the best conditions for the growth and development of the crops.

\section{A. Maximize the Amount of Organic Matter in the Soil}

This way we can easily achieve the desired productivity with lower production cost. This can be achieved through the application of agroforestry techniques, intercropping, crop rotation, and planation of cover crops to maximize biomass for soil protection and rehabilitation. When there is a lot of green matter for livestock feed, the animal husbandry develops and promotes the cultivation and development of the forest towards sustainable development. This also facilitates the development of organic agriculture (also called agro-ecology).

\section{B. Continuously Cover Land with Live or Dried Vegetation Cover}

This is the most important, multi-use method and the basis for all sustainable land-use management and use efforts towards eco-agriculture. Nylon can be used to cover sloping land, but must cover under the beds of the slope and the grooves between beds should be covered with vegetation. The best reuse of available organic matter is to burn out residues as farmers often do, but instead use them as cover material to protect and rehabilitate the land.

Benefits of land cover:

- Local benefits: Reduce erosion by rain and wind: Soft soil, increase soil water absorption, reduce surface runoff; Reduce evaporation, increase soil moisture; balance the soil surface structure; Increase the stability of soil surface structures, fight and clump the soil surface; Reduce weeds, increase fertilizer efficiency; reduce investment, land preparation, weeding, fertilizer; increase organic matter and nutrients for the soil, reduce toxins in the soil; Good conditions for good seed germination, strong root growth, good plant growth; Increase and stabilize crop productivity and quality in a sustainable way.

- The benefits of environmental protection and resource management: Limit shifting cultivation, improve soil, water and forest resources; prevent the deposition of rivers and lakes, especially hydroelectric reservoirs; reduce floods in the lowlands; Reduce chemical pollution in surrounding zones; Reduce the greenhouse effects by reducing the amount of carbon dioxide released into the air due to deforestation, plant residues and fumes from fertilizer and chemical plants; save energy used for fertilizer and chemical plants and operate soil tillers.

- Social benefits: Women are released from hard and time consuming work such as weeding and tillage. They will have more time to take care of family health, raise children and develop secondary occupations; Children will have more time to learn, improve their knowledge; land and water are less polluted, diseases will decrease, public health will be improved; Due to high economic efficiency, the society will develop faster and more sustainably.

Thus, when applying land cover effectively, most of the demand for sustainable sloping land cultivation can be applied, contributing to hunger elimination and poverty reduction for mountainous farmers and protection of environmental resources.

\section{Do Not Prepare the Soilor Prepare the Soil at Minimum Level}

For sloping land, if the soil is thoroughly prepared without cover, erosion will occur very rapidly. It can prepare the soil porous without having to plow the soil with mechanical means. It is the application of alternatives due to soil activity and the strong roots of some plant species (called biological plows).

\section{Rotation, Intercropping and Diversification of Crops}

Crop rotation, intercropping not only increase income but also increase biomass by using short-day, fast-growing, multifunctional species with strong and deep roots to exploit nutrients in the soil such as "nutrient pumping" or soil nutrient uptake by nitrogen fixation. In addition, intercropping of deep and shallow root systems should be planned in order to regulate nutrient and porosity of the soil. Crop rotation also has the effect of preventing accumulation of pests and diseases harmful to plants.

\section{E. Tree Planting is Mainly through Cover}

On many types of tropical humid soils due to low $\mathrm{pH}$ below 5, iron aluminum toxicity, soil compacted, therefore roots of the plants cannot grow. Under conditions of soil cover application, roots can be planted underground and from vegetative cover. In fact, many plant roots have a large suction area that lies close to the cover even in the cover if the moisture is maintained at an appropriate level. In many cases, the application of fertilizers into the cover layer is more effective than applying it to the soil.

\section{F. Some Other Effects}

By implementing the above principles, we are able to produce enough food and crops to meet the needs of life on fixed land and will not have to cut down forest for production. As such, forest coverage will increase and forests will protect people from natural disasters such as floods and droughts. Forests will provide us with many high value 
products to improve our lives. Animal husbandry also develops and helps farmers get rich without detriment to agricultural and forestry production. We will have clean products to ensure health without high investment, not dependent on the source of inorganic fertilizers. Women's burdens will be removed because they do not have to cut grass for livestock, do not waste much on weeding and tillage. Opportunities will have more to develop traditional trades and restore cultural values of ethnic minorities. Natural resources will be used properly and the environment is protected. With beautiful landscapes, we can expand ecotourism, increase incomes, contribute to eradicating hunger elimination and poverty reduction and proceed to get rich in a sustainable way.

\section{SOME AdVANCED TECHNIQUES IN SHIFTING} CUlTIVATION UNDER THE AGRO-ECOLOGY DIRECTION

\section{A. Afforestation or Zoning for Regeneration of Natural} Forests, Combined with the Planting of Short-term Food Crops in the Early Period or the Planting of Fruit Trees and Industrial Trees

Milpa on the rocky mountain, thin soil layer: Used mainly for production forest. The state supports afforestation for high economic efficiency. Create conditions for people to make long-term and stable business in such milpa.

Milpa on the land area is planned for watershed protection: Assign households to plant protection forests or zoning off for natural regeneration, which can be zoned for management by village communities, not burn for natural regeneration of the forest.

Create conditions for people to plant protective forests in combination with planting short-term food crops in the early period or planting fruit trees and industrial trees. Species are plants suitable for each site and ecological conditions of each region, multi-functional species (both have the ability to protect the environment, protect the soil, and have the ability to provide non-timber forest products). Depending on the local land fund, land is allocated to households on the basis of the design of the cropping systems.

\section{B. Improvement of Degraded Soils in Bare Hills with Cover Species with Strong Root Systems and Nitrogen Fixed Pea Crops}

Improve the soil's physical and chemical properties by breaking up the soil so that the soils are more porous and absorbent.

The deep-rooted system will utilize soil nutrients to provide large biomass for animal husbandry and soil protection, prevention of soil erosion and soil improvement, as well as to produce top cover material.

Nutrient, water and air circulation help the plants develop roots to absorb more nutrients and improve yield.

Enhance the activity of soil organisms, enrich the soil with worms, crickets, beetles, dissolved phosphorus and cellulose.
Grasses are capable of breaking down the surface solids through strong roots such as Humi grass, Signal grass, Guinea grass, Ruzi grass. They have a strong root system, therefore, the growth will make the soil more porous. In addition, they have large biomass (50 - 70 tons / ha) as nutrient-rich food for livestock, or cover the soil.

The most promising bean varieties are wild bean, coyote, rounded double leaf, stylo bean, wild boar, bean sprout, light bean and some other beans such as soybeans, striped bean. Currently they are being collected and surveyed to combine the propagation of these species for the purpose of implementing soil improvement, weeding and the production of animal feed.

\section{Restriction of Soil Erosion on Sloping Land with the Cover Trees}

Creating land cover will significantly reduce soil erosion. In addition, soil cover also has a positive effect on soil structure and soil improvement. Covered land will produce higher yield and stability.

Cover crops can be grown purely on land plots, rotating in short-term crops, in rows of orchards in open or closed forest.

\section{Intercropping and Rotation}

All crop species, fruit trees, industrial crops, and forest trees can be intercropped or rotated with cover crops to improve soil and other short-term crops to increase income.

1) Intercropping of spring mucuna gigantea and summer crops: Growing mucuna gigantea in March, breaking mucuna gigantea in early June with a knife or sickle, then poking holes in the seeds. To avoid damage to seeds and seedlings, the sowing holes need to be empty. If necessary, $30 \mathrm{~kg}$ of nitrogen / ha (or about $2 \mathrm{~kg}$ of commercial urea /parcel) can be applied before sowing to make the saplings grow faster. The plants then absorb the nutrients by breaking down the cover.

2) Intercropping spring maize with mucuna gigantea: In order to restrict the competitiveness, mucuna gigantea is sown after the maize has been 50 days old. After harvesting the spring maize, mucuna gigantea can be retained to cover the soil and harvest the seed for the next crop. If maize or winter crops are sown, mucuna gigantea and maize stalks are spread close to the ground, waiting for them to wilt and pierce the holes. It is possible to can substitute casserole with grape seed, strips of bean paste, beans to increase income. However, due to the larger biomass and the faster growth, mucuna gigantea has the best soil improvement potential.

3) Maize season alternating mucuna gigantea: As mentioned above, mucuna gigantea is sown 50 days after maize. After harvesting maize, mucuna gigantea will continue to green until January next year. Mucuna gigantea can be used as winter food for cattle or just to cover and improve the soil. With this approach, the next crop will 
grow with higher productivity while lower investment. However, if only growing crops in the crop, spring crops need additional saplings to maintain the cover and increase the biomass used to cover the soil in the crop. Without doing so, the weeds will grow and make it difficult to prepare the field for sowing. Other climbing species can also be used as mucuna gigantea. This depends on the choice of the farmers, but the way to do it is the same.

4) Maize or rice mixed with Arachis pintoi: Arachis pintoi is a non-climbing legume that only spreads on the ground, has good pest resistance and can grow on poor soil; with good shade resistance. This is also a high quality cattle feed. Arachis pintoi are a great cover for weed. It is grown in orchards to improve soil fertility, and is used to cover maize land and upland rice land. Cutting Arachis pintoi in the range of 30- to 40-centimeters and then drill the maize grain hole into two edges of the cuttings. After 20 to 30 days, Arachis pintoi will spread out and cover the maize. The results are very positive: Maize yields reach 40 tonnes / ha without weeding, tillage. Under the cornucopia, Arachis pintoi grows well and produces large biomass. Arachis pintoi is perennial, therefore, they do not have to be replanted. Clearly planting Arachis pintoi is a simple measure, reducing labor costs, liberating women so that they have time to educate their children or do other incomegenerating jobs and produce sustainability. Arachis pintoi is planted with wires, not self-propagating, therefore, there is no danger of developing beyond human control.

5) Planting cassava with peanuts: Farmers are still intercropped with cassava with some trees such as beans, soybeans, green beans and etc. People in some place also plant cassava with peanuts but due to the low yield of old varieties, it does not reach the haversting crop. Thrrefore, recently, many local farmers have planted only vegetarian cassava. Meanwhile, cassava roots cause the most soil erosion, therefore, after planting within two or three years, it is to abandon the land. In fact, the cassava area in many countries and regions has decreased markedly. However, thanks to the achievements in breeding, there are now many varieties of high-yielding, drought-tolerant and very good green trees. Many new cassava varieties with remarkable yields have been put into production to allow the application of cassava-peanut cultivation in order to be both economically effective and protect and increase soil fertility.

\section{E. Shorten or Ignore the Fallow Stage}

Normally, from 3 to 4 crops of upland rice, farmers grow cassava and harvest them gradually for 3 years, then fallow. It is possible to plant cassava with legumes such as Stylo, Cassia, beans for soil protection and improvement. After harvesting cassava, it can continue to grow food crops. It is also possible to improve fallow land with specialized grass species and pea trees to improve livestock income during the "active" fallow period.

Positive management of fallow land: Planting shrubs and grasses such as Acacia mangium, Acacia sprouts, pea, kerosene. These plants will improve soil rapidly in 3 to 5 years and still give income (food for people, livestock, wood, firewood, seeds).

\section{F. Make Rapid Land Improvement by Land-burning}

In fact, farmers prefer to burn the forest and crop residue because they find that in growing areas, plants grow better. Some farmers have used muddy soil to fill the bark of the brick kiln and then applied the fertilizer to reduce fertilizer investment. Local land burning also gives the same effect. The application method is as follows: Dig $30 \mathrm{~cm}$ deep x 30 $\mathrm{cm}$ wide; lining the bottom of the groove with small branches, straw, grass $15-20 \mathrm{~cm}$ thick; Spread a layer of straw $5 \mathrm{~cm}$ thick and then cover the soil $10 \mathrm{~cm}$; Except for points blank 1m apart from donkeys; set fire to straw; Pay close attention to the fire. Then the fire will be vegetarian and simmer for 2-3 days. Remember to choose the sunny days to burn. In the dry season, it is possible to burn the soil, then plant the cover trees. In the planting crop, it is necessary to destroy the cover crop. If it is a legume, need to use knives, sickle trees near the ground; If grass 1 is a germ, herbicide is applied (should use non-toxic Glyphosate for humans, livestock and shrimps, fishes); 10 days later, drill holes along two the edges of grooves. It is important to maintain the vegetation cover and intercropped with legumes in order to improve the soil, otherwise it will be difficult to grow in later crops. Do not use branches as they are difficult to burn all, if burned out, high burning temperature negatively affect the soil? It is not advisable to continuously cultivate land that has been cultivated for 4-5 years. It is best to use the landburning based method only after thorough training to avoid the risk.

\section{G. Make the Sub Terraces on too Steep Land}

The steeper the land is, the sooner it will degenerate. Incorporating sub terraces for land cover will adversely affect this phenomenon. Stairs are also useful for intensive cultivation because they retain fertilizer, facilitating care and harvesting.

Method of implementation: Clean grass and arrange them to the side; Use pads, hoes to level the land into sub terraces with a surface of $30-40 \mathrm{~cm}$. It is important to be at the bottom of the slope to the top of the slope so that the topsoil of the next terrace (above) will cover the previous terrace (bottom) and not overcrowded. Use grass weed leaves cover the surface and then drill holes. If the plants are weak, they must be fertilized. Grow arachis pintoi or grass on the terrace edge to stabilize the terrace and create soil cover. When the grass grows on a well-formed terrace, cut and cover with a sickle, do not use hoes or choppers to weed. After harvesting, retain maizestalks, rice to cover and improve the soil. In the next crop, just clear the grass and dig the holes. In this way, the productivity of maize and rice will increase over time.

\section{H. Make a Living Fence, Trenches to Protect the Field}

Due to the pressure of free breeding, the protection of the field is very important. Digging, dividing stone walls, building green fences is effective measures. Thanks to the protection, we can increase crop rotation, increase land use 
and stabilize productivity. This is not technically demanding, but the key is the choice of Randia spp, Euphorbia pulcherimao, Jatropha curcas, Sterculia spp, Erthryna spp; Acacia spp; Caesalpinia sapan; Gliricilia sepium; Pennisetum purpureum and etc.

\section{Elimination of Organic Grass}

Mucuna gigantea is used to remove the grass as well as other grass species, then plant maize: cut the grass, wait for growing up 15-20 cm, and apply Glyphosate (3 liters / ha), wait for 10 days, sow mucuna gigantea. Mucuna gigantea is fast-growing, healthy plants should kill the grass very well. In addition, mucuna gigantea also provides a lot of protein to the soil, therefore, the yield of the latter crop will be higher and the fertilizer investment will be reduced.

Using a variety of grass species such as Brachiaria, Guinea, Stylo, Cassia ... with high utilization value and also good coverage can be used to kill other species of weeds.

\section{CONCLUSION}

In the context of rapid population growth, reduced cultivation land and, to deal with climate change, we need to protect soil and water resources, especially sloping land. As mentioned above, sloping land contains a lot of potential for development, but it is very vulnerable to the ecosystem, therefore, a holistic and environmentally friendly approach is required. Recent approaches to Agro-ecology or Conservation Agriculture (CA) are being studied by many countries, including Vietnam.

The results show that the management of shifting cultivation towards an agro-ecology approach is indispensable in the sustainable management and use of sloping land. This in fact has significantly increased yields on sloping crops, reduced erosion and income diversification for farmers while preserving resources and improving the environment, contributing to hunger elimination and poverty reduction and achievement of food security goals for the uplands.

\section{REFERENCES}

[1] Le Quoc Doanh, Nguyen Van Bo and Ha Dinh Tuan, "Upland agriculture: Current situation and solutions", Agricultural Publishing House, Hanoi, 2003.

[2] Le Quoc Doanh, Ha Dinh Tuan and Andre Chabanne, "Sustainable sloping land cultivation", Agricultural Publishing House, Hanoi, 2005

[3] Le Trong Cuc, "Slope cultivation in Vietnam", Hanoi Agricultural Publishing House, 1995.

[4] Tran Duc Vien, "Agriculture on Sloping Land: Challenges and Potential”, Agricultural Publishing House, Hanoi, 1996.

[5] Bui Huy Hien, "Mountainous land: situation of use, erosion, degradation and measures to protect and improve fertility. In Upland Agriculture, Current Situation and Solutions", Agricultural Publishing House, Hanoi, 2003.

[6] Thai Phien and Nguyen Tu Siem, "Sustainable cultivation on sloping land in Vietnam", Agricultural Publishing House, Hanoi, 1998.

[7] Thai Phien and Nguyen Tu Siem, "Sustainable use of mountainous and high land in Vietnam", Agricultural Publishing House, Hanoi, 2002.
[8] Nguyen Tu Siem and Thai Phien, "Mountainous land of Vietnam: degradation and restoration", Agricultural Publishing House. Hanoi, 1999.

[9] Tran Duc Vien, "Experience in post-fallow land management in Vietnam”, Agricultural Publishing House, Hanoi, 2001.

[10] Erangelista P. P. and Urriza G. I. P etc, "Effect of organic matter, lime and phosphorus fertilizers on acid upland soil", ACIAR project 9414 annual report, Philippines, 1999.

[11] Ernst Mutert and Thosmat Fairhurst, "Nutrient management on sloping land of Southeast Asia, constraints, challenges and opportunities", Workshop on nutrient and water management for upland crop in northern Vietnam, Hanoi, 13-14 January 1997. 